\title{
Nutritive evaluation of different energy sources in broiler chicken diets under the tropical climate of Nigeria \\ **Jirgi, D. J. and ${ }^{2}$ Abeke, F. O. \\ **Federal Ministry of Agriculture and Rural Development, P.M.B 135, FCT Garki, Abuja. Nigeria

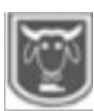 \\ Abstract \\ ${ }^{2}$ National Animal Production Research Institute, Shika Zaria, Kaduna State. Nigeria.
}

This study was aimed at evaluating the nutritive value of different sources of energy in broiler chicken diets on the growthperformance and haematological parameters of broiler chickens. Five isonitrogenous and isocaloric diets $(23.17 \%$ CP; $2831 \mathrm{Kcal} / \mathrm{ME} ; 21.73 \% \mathrm{CP}$; $2929 \mathrm{Kcal} / \mathrm{ME}$ ) for the broiler starter (0-4 weeks) and finisher phases (5-8 weeks), respectively were formulated. Treatment 1 is the control diet while treatments 2, 3, 4 and 5 were sorghum, pearl millet, cassava and sweet potatoesbased diets, respectively. A total of 225, 1 day-old NAPRI X broiler chicks wererandomly allotted to the five treatmentswith three replicates each in a Completely Randomized Design (CRD). Data were subjected to ANOVA $\alpha_{0.05}$. The results showed that finalbody weights $(503.44 \mathrm{~g}$ and $2302.77 \mathrm{~g}$ ), feed intake $(819.67 \mathrm{~g}$ and $3073.70 \mathrm{~g})$ and weight gained $(453.61 \mathrm{~g}$ and $1892.07 \mathrm{~g})$ were significantly $(P<0.05)$ higher in birds fed millet diets $(T 3)$ than other treatments for both starter and finisher phases, respectively. T3 (millet based diet) recorded significantly $(P<0.05)$ the best feed conversion ratio (1.62) and thelowest feed cost per $\mathrm{kg}$ weight gain (145.90) at the finisher phase whilechicks fed the control (maize based diet (T1) and sorghum (T2) based diet gavesimilar ( $P>0.05)$ values as those fed T3 (millet based diets). Birds fed diet T5 (sweet potatoes) gave significantly $(P<0.05)$ lowestvalues in all parameters measured and poor feed conversion ratio at the starterphase. Similar pattern was also observed in the finisher phase except in feed intake and mortality which were comparable with other dietary treatments. Dietary treatments had significant $(P<0.05)$ effect on white and red blood cells of broiler birds fed different energy sources. Millet based diet was the best in terms of nutritive value and also in terms of cost of production without compromising productivity in broiler chickens. It is also recommended that other methods of processing millet should be exploited. Keywords: Feedstuff, nutritive value, energy sources, hematological parameters

\section{Introduction}

Animal agriculture in developing countries such as Nigeria is confronted with various challenges. These problems include feed shortage, high prices of feedstuffs and climate variations (Belewu et al., 2007). Protein and energy are the most costly components in poultry diets, especially the plant protein (Mukhtar, 2007). The effects of these challenges have reflection on the quality and quantity of animal protein available for human consumption (Agbabiaka, 2010) and the health status.
The major factor militating against increase in poultry production is the non-availability of feed at economic price. Most of the energy concentrates are very expensive since they are also staple food for our everincreasing human population. However, there is a need to evaluate different energy sources so as to make better choices of which to use when all are available and when prices of the conventional energy sources such as maize is high, information on other sources become necessary to keep production on. Therefore, the aim of this 
study is to compare the growthperformance and haematological parameters of broilers chickens fed maize, sorghum, millet, cassava and sweet potatoes as energy sources.

\section{Materials and methods}

A total of two hundred and twenty five (225) day-old broiler chicks (mixed sexes) were used for the research from the National Animal Production Research Institute (NAPRI) Zaria, Kaduna State, Nigeria. The chicks were weighed and randomly assigned into five groups of 45 birds which were subdivided into three replicates per group in a Completely Randomized Design (CRD). Feed and water were provided ad libitum during the trial period which lasted for 56 days. Weighing of birds was done at the beginning of the trial and weekly thereafter. Parameters taken were weight gain, feed intake, left over feeds were measured and recorded, feed conversion ratio and feed cost per kilogramme gain were calculated and mortality rate were recorded. Five isonitrogenous and isocaloric diets (23.17 $\% \mathrm{CP} ; 2831 \mathrm{Kcal} / \mathrm{kg} \mathrm{ME})$ and $(21.73 \% \mathrm{CP}$; $2929 \mathrm{Kcal} / \mathrm{kg}$ ) for the broiler starter and finisher phases, respectively were formulated as follows:

Diet 1: Contained maize as main energy

Diet 2: Contained sorghum as main energy

Diet 3: Contained millet as main energy

Diet 4: Contained cassava as main energy

Diet 5: Contained sweet potatoes as main energy.

The main energy sources were used as diets to feed the experimental groups $\mathrm{T}_{1}, \mathrm{~T}_{2}, \mathrm{~T}_{3}, \mathrm{~T}_{4}$ and $\mathrm{T}_{5}$, respectively (Table 1 and 2 ). All diets were formulated to meet nutrient requirement standards of broilers (NRC, 1994).

\section{Haematological parameters}

Six birds were randomly chosen from each group and $2 \mathrm{mlsof}$ blood was collected from each of them via the wing vein and put into a sample bottle containing anti-coagulant (Ethylene Di-amine Tetra Acetic Acid EDTA). The stored blood sample was analyzed for packed cell volume (PCV), Haemoglobin level (HB) and total protein (TP) according to procedures described by Lamb (1991) at the haematological laboratory of Veterinary Teaching Hospital, Ahmadu Bello University, Zaria.Statistical analysis

All data were subjected to Analysis of Variance (ANOVA) using the General Linear Model of SAS (2002). Significant differences between treatment means were separated using Duncan's Multiple Range Test of the SAS package.

\section{Results and discussion}

Table 1 shows the growth characteristics of broiler starter chicks fed diets containing different energy sources. Dietary treatment had significant $(\mathrm{P}<0.05)$ effects on final weight, weight gain, feed intake, feed gain ratio, feed cost $/ \mathrm{kg}$ gain, water intake, water: feed ratio and mortality. It was observed from this present study that chicks fed millet as main energy (T3) had significantly $(p<0.05)$ the best result in terms of final weight, weight gain, feed intake and feed conversion ratio. Chicks fed sweet potatoes as main energy had significantly $(\mathrm{P}<0.05)$ the highest feed cost per/kg gain. Chicks fed maize had the highest water intake. Mortality rate was higher in chicks fed sweet potatoes as main energy compared to other treatments. The differences in final weight, weight gain, feed intake, feed to gain ratio and water intake of birds fed millet diets might be due to more balanced nutrient combination in millets since required amount of the essential amino acids is necessary for protein synthesis which results in increased weight gain. This agreed with the reports of Rooney (1990) that millets contain more balanced amino acids than other common cereal grains which may enhance growth performance. 


\section{Jirgi and Abeke}

Table 1: Performance characteristics of broiler chicks fed different energy sources ( 0 -4 weeks)

\begin{tabular}{lllllll}
\hline Parameters & $\mathbf{T}_{1}$ & $\mathbf{T}_{\mathbf{2}}$ & $\mathbf{T}_{\mathbf{3}}$ & $\mathbf{T}_{\mathbf{4}}$ & $\mathbf{T}_{\mathbf{5}}$ & \\
\hline Initial weight (g/bird) & $49.6 \pm 2.7$ & $49.9 \pm 2.7$ & $49.8 \pm 2.7$ & $49.7 \pm 2.5$ & $50.0 \pm 2.4$ & $\mathrm{NS}$ \\
Final Weight (g/bird) & $420.2 \pm 27.1^{\mathrm{b}}$ & $445.7 \pm 24.3^{\mathrm{b}}$ & $503.4 \pm 21.2^{\mathrm{a}}$ & $251.7 \pm 20.6^{\mathrm{c}}$ & $285.4 \pm 18.7^{\mathrm{c}}$ & $*$ \\
Weight gain (g/bird) & $370.6 \pm 16.4^{\mathrm{b}}$ & $383.7 \pm 15.0^{\mathrm{b}}$ & $453.6 \pm 17.5^{\mathrm{a}}$ & $201.9 \pm 16.0^{\mathrm{c}}$ & $235.4 \pm 15.9^{\mathrm{c}}$ & $*$ \\
Feed Intake (g/bird) & $676.7 \pm 32.0^{\mathrm{b}}$ & $735.8 \pm 31.1^{\mathrm{b}}$ & $819.6 \pm 30.9^{\mathrm{a}}$ & $545.4 \pm 28.7^{\mathrm{c}}$ & $759.5 \pm 30.4^{\mathrm{ab}}$ & $*$ \\
Feed/conversion ratio & $1.9 \pm 0.8^{\mathrm{a}}$ & $1.9 \pm 0.8^{\mathrm{a}}$ & $1.8 \pm 0.6^{\mathrm{a}}$ & $2.7 \pm 1.0^{\mathrm{b}}$ & $3.3 \pm 1.2^{\mathrm{c}}$ & $*$ \\
Feed cost/kg gain & $168.5 \pm 8.3^{\mathrm{a}}$ & $177.4 \pm 8.1^{\mathrm{ab}}$ & $173.3 \pm 8.7^{\mathrm{a}}$ & $266.41 \pm 8.2^{\mathrm{b}}$ & $311.3^{\mathrm{a}} \pm 7.8^{\mathrm{c}}$ & $*$ \\
Water Intake (mls/bird) & $1387.3 \pm 50.4^{\mathrm{a}}$ & $1350.4 \pm 55.2^{\mathrm{a}}$ & $1376.1 \pm 52.9^{\mathrm{a}}$ & $1265.2 \pm 53.9^{\mathrm{b}}$ & $1274.2 \pm 50.1^{\mathrm{b}}$ & $*$ \\
Water: Feed ratio & $2.05 \pm 1.1^{\mathrm{b}}$ & $1.84 \pm 1.3^{\mathrm{c}}$ & $1.68 \pm 0.8^{\mathrm{d}}$ & $2.32 \pm 1.3^{\mathrm{a}}$ & $1.68 \pm 0.9^{\mathrm{d}}$ & $*$ \\
Mortality Rate (\%) & $0.70 \pm 0.2^{\mathrm{c}}$ & $0.16 \pm 0.7^{\mathrm{a}}$ & $0.20 \pm 0.9^{\mathrm{b}}$ & $0.16 \pm 0.6^{\mathrm{a}}$ & $3.30 \pm 1.2^{\mathrm{d}}$ & $*$ \\
\hline
\end{tabular}

${ }^{a b c}$ Means in the same row with different superscript are significantly different.

Table 2 shows the performance characteristics of broiler finisher chickens fed diets with different energy sources. Dietary treatments had significant $(\mathrm{P}<0.05)$ effects on final weight, weight gain, feed intake, feed conversion ratio, feed cost $/ \mathrm{kg}$ gain, water: feed ratio and mortality rate. Chickens fed millet as main energy (T3) has significantly $(\mathrm{P}<0.05)$ the best values for final weight, weight gain, feed intake, feed cost/kg gain. Millet fed chickens (T3) had the best feed conversion ratio (1.62) as compared to other treatments while cassava fed chickens (T4) consumed more water (3918.30mLs/b) compared to birds in other dietary treatments. This is an indication that millet contains more essential nutrients as compared to other cereals used in this study. This confirmed the observation of Adeola
(2006) that pearl millet contains 27 to $32 \%$ more protein than maize with higher concentration of essential amino acids. Highest feed intake observed in the treatments fed sorghum and millet was attributed to increase feed palatability as both sorghum and millet have been reported to enhance palatability (Amini and RuizFeria, 2007). Rao et al. (2001) observed significantly higher feed intake when broiler chicks were fed millet based diets. The steady decline in body weight gain of the broilers fed cassava as a source of energy may be attributed to the concomitant reduction in feed intake with increase in the inclusion levels of cassava peels. The reduction in feed intake may be associated with the residual cyanide which is inherent in cassava peels.

Table 2: Performance characteristics of broiler finisher chicken fed different energy sources (5 -8 weeks)

\begin{tabular}{lllllll}
\hline Parameters & $\mathbf{T}_{\mathbf{1}}$ & $\mathbf{T}_{\mathbf{2}}$ & $\mathbf{T}_{\mathbf{3}}$ & $\mathbf{T}_{\mathbf{4}}$ & $\mathbf{T}_{\mathbf{5}}$ & \\
\hline Initial weight (g/bird) & $510.5 \pm 26.4$ & $510.6 \pm 27.1$ & $510.7 \pm 25.9$ & $510.7 \pm 26.0$ & $510.8 \pm 26.2$ & $\mathrm{NS}$ \\
Final Weight (g/bird) & $2087.1 \pm 66.6^{\mathrm{ab}}$ & $2130.9 \pm 69.1^{\mathrm{b}}$ & $2302.7 \pm 60.8^{\mathrm{a}}$ & $1681.1 \pm 68.4^{\mathrm{c}}$ & $1711.1 \pm 59.9^{\mathrm{c}}$ & $*$ \\
Weight gain (g/bird) & $1576.5 \pm 25.9^{\mathrm{b}}$ & $1620.3 \pm 24.8^{\mathrm{b}}$ & $1892.0 \pm 26.2^{\mathrm{a}}$ & $1170.4 \pm 26.8^{\mathrm{c}}$ & $1200.3 \pm 25.7^{\mathrm{c}}$ & $*$ \\
Feed Intake (g/bird) & $2984.8 \pm 1.7^{\mathrm{b}}$ & $3019.7 \pm 1.4^{\mathrm{a}}$ & $3073.7 \pm 1.9^{\mathrm{a}}$ & $2515.2 \pm 1.6^{\mathrm{d}}$ & $2739.4 \pm 1.4^{\mathrm{c}}$ & $*$ \\
Feed/gain ratio & $1.9 \pm 0.3^{\mathrm{b}}$ & $1.9 \pm 0.3^{\mathrm{b}}$ & $1.6 \pm 0.1^{\mathrm{a}}$ & $2.2 \pm 0.9^{\mathrm{c}}$ & $2.3 \pm 0.11^{\mathrm{d}}$ & $*$ \\
Feed cost/kg gain & $167.7 \pm 9.6^{\mathrm{b}}$ & $162.4 \pm 10.1^{\mathrm{b}}$ & $145.9 \pm 9.2^{\mathrm{a}}$ & $197.2 \pm 9.7^{\mathrm{c}}$ & $204.4 \pm 10.6^{\mathrm{c}}$ & $*$ \\
Water Intake (mLs/bird) & $3846.2 \pm 1.2^{\mathrm{e}}$ & $3886.6 \pm 1.7^{\mathrm{c}}$ & $3905.3 \pm 1.5^{\mathrm{b}}$ & $3918.3 \pm 1.3^{\mathrm{a}}$ & $3875.2 \pm 1.9^{\mathrm{d}}$ & $*$ \\
Water: Feed ratio & $1.3 \pm 0.1^{\mathrm{a}}$ & $1.3 \pm 0.2^{\mathrm{a}}$ & $1.3 \pm 0.1^{\mathrm{a}}$ & $1.6 \pm 0.9^{\mathrm{c}}$ & $1.4 \pm 0.6^{\mathrm{b}}$ & $*$ \\
Mortality Rate (\%) & $2.2 \pm 0.8^{\mathrm{b}}$ & $4.4 \pm 1.3^{\mathrm{c}}$ & $6.7 \pm 1.0^{\mathrm{d}}$ & $0.00 \pm 0.0^{\mathrm{a}}$ & $0.00 \pm 0.0^{\mathrm{a}}$ & $*$ \\
\hline
\end{tabular}

${ }^{a b c}$ Means in the same row with different superscript are significantly different. SEM= standard error of means.

Table 3 shows the haematological parameters of broiler chicken fed different energy sources. Pack cell volume, total protein and haemoglobin were not significantly $(\mathrm{P}>0.05)$ affected by the different energy sources with the exception of white and red blood cells. The values obtained in this study for $\mathrm{Hb}, \mathrm{PCV}$ and TP 
were similar to $6-13.0 \%, 29.0-38.0 \%$ reported bylheukwumere and Herbert (2003) for $\mathrm{Hb}$ and PCV, respectively. This implied that the feedstuff did not pose adverse effects on the health status of the birds.

Table 3: Haematological parameters of broiler finishe $r$ chickens fed different energy sources (5 -8 weeks)

\begin{tabular}{|c|c|c|c|c|c|c|}
\hline Parameters & Maize & Sorghum & Millet & Cassava & $\begin{array}{l}\mathbf{T}_{5} \\
\text { Sweet } \\
\text { potatoes }\end{array}$ & LOS \\
\hline $\mathrm{PCV}(\%)$ & $30.7 \pm 2.8$ & $26.3 \pm 2.2$ & $29.0 \pm 3.1$ & $25.7 \pm 2.5$ & $25.7 \pm 2.7$ & NS \\
\hline $\mathrm{Hb}(\mathrm{g} / \mathrm{dl})$ & $10.2 \pm 2.1$ & $9.3 \pm 1.8$ & $9.6 \pm 2.7$ & $8.5 \pm 2.2$ & $8.5 \pm 2.0$ & NS \\
\hline T.P (g/dl) & $2.7 \pm 0.3$ & $3.3 \pm 0.5$ & $3.1 \pm 0.6$ & $3.4 \pm 0.9$ & $2.9 \pm 0.8$ & NS \\
\hline WBC $\left(10^{3} / \mathrm{ml}\right)$ & $2.9 \pm 1.6^{\mathrm{b}}$ & $4.2 \pm 1.3^{\mathrm{a}}$ & $3.9 \pm 1.1^{\mathrm{a}}$ & $1.8 \pm 1.5^{\mathrm{c}}$ & $2.3 \pm 1.3^{\mathrm{b}}$ & $*$ \\
\hline $\mathrm{RBC}\left(10^{6} / \mathrm{ml}\right)$ & $3.8 \pm 0.5^{\mathrm{a}}$ & $4.8 \pm 0.3^{\mathrm{a}}$ & $5.0 \pm 0.8^{\mathrm{a}}$ & $1.5 \pm 1.2^{\mathrm{b}}$ & $2.6 \pm 1.1^{\mathrm{a}}$ & $*$ \\
\hline
\end{tabular}

Hb-Haemoglobin, TP-Total protein, PCV-Pack cell volume, WBC-White blood cell,

RBC-Red blood cell, NS-Not significant

\section{Conclusion}

The following conclusion and recommendations could be drawn from this study; Millet based diet was determined to be the best with reduced cost of production without compromising productivity in broiler chickens. Energy sources influenced growth characteristics. White and Red blood cells varied within dietary groups. It is also recommended that other methods of processing millet should be exploited and studied within the same environment to evaluate the overall suitability of millet as an unconventional feed ingredient in poultry nutrition.

\section{Conflict of interest}

The authors have not declared any conflict of interest.

\section{References}

Adeola, O. 2000. Amino acid digestibility in corn, pearl millet, and sorghum for White Pekin ducks (Anasplatyrinchosdomesticus). Japanese Poultry Science, 43:357-364.

Amini, K. and Ruiz-Feria, C. A. 2007. Evaluation of pearl millet and flaxseed effects on egg production and n-3 fatty acid content. British Poultry Science, 48:661-668.
Iheukwumere, F. C. and Herbert, U. 2003. Physiological responses of broiler chickens to quantitative water restrictions: Haematology and serum biochemistry. International Journal of Poultry Science, 2: 117119.

Lamb, G. N. 1991. Manual of Veterinary Laboratory Technique. Ciba-Geigy Ltd., Kenya, pp: 98-99.

NRC 1994. National Research council. Nutrient requirements of poultry $9^{\text {th }}$ Revision Edition National Academy press, Washington, D. C.

Rao, S. V., Shyam Sunder, G. I., Reddy, M. R., Praharaj, N. K., Raju, M.V. and Panda, A. K. 2001. Effect of supplementary choline on the Performance of broiler breeders fed on different energy sources. Journal of British PoultryScience, 42:362-367.

Rooney, L. W. 1990. Sorghum and Pearl millet lipids. Journal of Cereal Chemistry, 55: 584-590.

Statistical Analysis System. 2002. Users guide statistics, Version 6 Edition, SAS institute Inc. Cary. North Carolina, U.S.A.

Received: $24^{\text {th }}$ May, 2018

Accepted: 30 ${ }^{\text {th }}$ August, 2018 